\title{
Tissue-specific response of IGF-I mRNA expression to obesity-associated GH decline in the male Zucker fatty rat
}

\author{
E Melián, B González, R Ajo, N González and F Sánchez Franco \\ Servicio de Endocrinología, CIC, Instituto de Salud Carlos III, Madrid, Spain \\ (Requests for offprints should be addressed to E M Melián, Servicio de Endocrinología, CIC, Instituto Carlos III, C/Sinesio Delgado 10, 28029 Madrid, Spain)
}

\begin{abstract}
Diminished GH secretion is a well known association of obesity. As in obese humans, Zucker fatty rats develop a progressive GH deficiency, present at 6 weeks of age and maximal at 10 to 12 weeks. The aim of this study was to investigate the GH dependence of IGF-I gene expression in liver and extrahepatic tissues of the obese Zucker rat as a model of progressive $\mathrm{GH}$ reduction during adult life. Six- and 11-week-old obese Zucker rats and their lean littermates were used to compare body weight, glycemia, insulinemia, serum GH and IGF-I levels and IGF-I mRNA expression in liver, heart, aorta, kidney and skeletal muscle. In comparison with lean controls, obese Zucker rats showed at both ages comparable glycemia, severe hyperinsulinemia $(\mathrm{mU} / \mathrm{ml}$, mean \pm s.E.M.; 6 weeks $138 \pm 10$ vs $45 \pm 6 \quad P<0 \cdot 001 ; 11$ weeks $147 \pm 14$ vs $46 \pm 3, \quad P<0.001)$ and lower $\mathrm{GH}(\mathrm{ng} / \mathrm{ml} ; 6$ weeks $1 \cdot 7 \pm 0.9$ vs $2 \cdot 7 \pm 1 \cdot 1 ; 11$ weeks $1.5 \pm 0.9$ vs $4 \cdot 2 \pm 1 \cdot 2)$ in the presence of similar circulating IGF-I levels $(\mathrm{ng} / \mathrm{ml} ; 6$ weeks $774 \pm 26$ vs $694 \pm 28 ; 11$ weeks $1439 \pm 182$ vs $1516 \pm 121)$. Hepatic IGF-I mRNA expression was already reduced at 6 weeks of age due to a significant decrease in the IGF-Ib transcript compared with lean controls (relative units; IGF-Ia: $99 \pm 2 \%$ vs $100 \pm 5 \%$;
\end{abstract}

IGF-Ib: $69 \pm 10 \%$ vs $100 \pm 2 \%, P<0 \cdot 05)$ and this reduction was more marked in 11-week-old animals when both IGF-I transcripts were significantly diminished (relative units; IGF-Ia: $80 \pm 6 \%$ vs $100 \pm 1 \%, P<0 \cdot 05$; IGF-Ib: $65 \pm 5 \%$ vs $100 \pm 2 \%, \quad P<0 \cdot 01)$. Extrahepatic tissues expressed almost exclusively the IGF-Ia transcript, the amount of which relative to controls was: (1) similar at 6 weeks and decreased at 11 weeks in kidney and skeletal muscle extracts (relative units; kidney: 6 weeks $88 \pm 10 \%$ vs $100 \pm 2 \%$; 11 weeks $76 \pm 3 \%$ vs $100 \pm 4 \%, P<0 \cdot 05$; vastus lateralis: 6 weeks $95 \pm 7 \%$ vs $100 \pm 10 \%$; 11 weeks $59 \pm 4 \%$ vs $100 \pm 2 \%, P<0 \cdot 001)$; (2) similar at both ages in thoracic aorta (relative units; 6 weeks $121 \pm 6 \%$ vs $105 \pm 5 \%$; 11 weeks: $91 \pm 14 \%$ vs $100 \pm 4 \%$ ); and (3) increased at both ages in left ventricle extracts (relative units; 6 weeks $114 \pm 2 \%$ vs $99 \pm 9 \%, P<0 \cdot 05$; 11 weeks $119 \pm 7 \%$ vs $95 \pm 3 \%, P<0 \cdot 05)$.

These data support the existence of tissue-specific dependence of IGF-I mRNA on GH levels during adulthood, reflected by the different behavior of IGF-I expression for each tissue in conditions of progressive decrease of GH levels.

Journal of Endocrinology (1999) 160, 49-56

\section{Introduction}

Insulin-like growth factor I (IGF-I) is involved in the promotion of growth and differentiation of a variety of vertebrate tissues (Daughaday \& Rotwein 1989). The liver is considered the primary source of endocrine IGF-I production in mammals, growth hormone $(\mathrm{GH})$ being the major regulator of hepatic IGF-I synthesis and secretion (Schwander et al. 1983). In addition to liver, many other tissues synthesize IGF-I with essentially autocrine/ paracrine functions but its regulation is less well known (D'Ercole et al. 1984, Moller et al. 1991). GH seems to regulate extrahepatic IGF-I production in conditions of severe deficit suggesting there is a minimal threshold level of this hormone below which local IGF-I production fails. Thus, IGF-I mRNA is decreased in variable degrees in most tissues of hypophysectomized (hx) rats and exogen- ous GH efficiently reverses this decrease (Murphy et al. 1987, Roberts et al. 1987). Two animal models of dwarfism have been used to study in vivo the GH dependence of IGF-I synthesis in extrahepatic tissues comparing it with regulation in the liver: the lit/lit mouse in which there are markedly reduced serum GH levels as a result of a recessive inactivating mutation (Mathews et al. 1986) and the sex-linked dwarf chicken lacking GH receptor protein because of an inappropriate splicing of the $\mathrm{GH}$ receptor gene transcript secondary to a mutation (Tanaka et al. 1996). In the first model, 13-week-old homozygous males showed a significant decrease in liver IGF-I mRNA level in the presence of a slight and GH-dependent decrease in kidney and brain, whereas expression in heart was increased but unchanged in testis and lung. In the second model, 4-week-old chickens with the mutant GH receptor showed no IGF-I mRNA expression in liver, but there 
were similar levels in extrahepatic tissues such as heart, muscle, testis or brain compared with normal controls. Aorta and kidney were not analyzed in this study.

The role of GH in extrahepatic IGF-I production in conditions of more physiological and progressive $\mathrm{GH}$ deficiency, such as associated with aging or obesity, is less well established and has been the recent focus of our laboratory research (Melián et al. 1997, Velasco et al. 1998). In this line of work the purpose of the present study was to characterize the IGF-I system in genetically obese Zucker rats as a model of obesity-associated relative $\mathrm{GH}$ deficiency. Using age-matched lean rats as controls, we examined serum IGF-I levels and IGF-I mRNA expression in liver, heart, aorta, kidney and skeletal muscle from 6-week-old rats (when the GH defect is already present) and 11-week-old rats (when it is maximal). To confirm dependency of $\mathrm{GH}$ in conditions of total endogenous lack of this hormone we also measured IGF-I mRNA in tissues from hx obese rats before and after one i.p. dose of GH.

\section{Materials and Methods}

\section{Animals and experimental design}

Male lean $(\mathrm{Fa} /-)$ and genetically obese $(\mathrm{fa} / \mathrm{fa})$ rats were obtained from Criffa (Barcelona, Spain). Animals were freely fed a standard chow (RMN Labsure, Biosure, Barcelona, Spain) and water, and were housed at constant temperature $\left(23^{\circ} \mathrm{C}\right)$ with a fixed $(12 \mathrm{~h}: 12 \mathrm{~h})$ light: darkness cycle. After adaptation, animals were anesthetized and killed by decapitation at $0900 \mathrm{~h}$. Blood was collected from the cervical vessels and serum was stored at $-20{ }^{\circ} \mathrm{C}$ until assayed for glycemia, insulinemia, rat $\mathrm{GH}$ and IGF-I. Liver, heart, aorta, kidneys and vastus lateralis muscle were removed rapidly, snap-frozen in dry ice, and stored at $-80{ }^{\circ} \mathrm{C}$. At the time of the experiments animals were 6 or 11 weeks old.

Hx male obese rats were delivered to our animal facility 7 days after hypophysectomy (Criffa, Lyon, France). The adequacy of hypophysectomy was assessed at the time of killing by visual inspection of sella turcica. Rats were housed for 5 days under controlled conditions, freely feeding and with water with $5 \%$ glucose and $0.9 \% \mathrm{NaCl}$. After adaptation, rats received one i.p. dose of $1.5 \mu \mathrm{g} / \mathrm{g}$ body weight of recombinant human $\mathrm{GH}(\mathrm{rhGH})$ and were decapitated 4 or $8 \mathrm{~h}$ later. At the time of the experiments animals were 11 weeks old. Tissues were collected and stored at $-80{ }^{\circ} \mathrm{C}$.

\section{RIAs and biochemical parameters}

IGF-I was measured by a commercial RIA (Nichols Institute, San Juan Capistrano, CA, USA) after acidethanol extraction. Rat $\mathrm{GH}$ was determined using the National Pituitary Hormone Distribution Program rat hormone kit (National Hormone and Pituitary Program of the National Institute of Arthritis, Metabolism and Digestive Diseases, Bethesda, MD, USA), with a sensitivity limit of $0 \cdot 8 \mu \mathrm{g} / 1$. Serum insulin was measured using a commercial kit (Coat-a-Count Insulin, Diagnostic Products Corp., Los Angeles, CA, USA) and serum glucose by the glucose oxidase method (ITC Diagnostics).

All the parameters were measured in serum from individual rats and the samples of groups to be compared were analyzed in the same assay, to avoid interassay variations.

\section{RNA probes}

IGF-I One construct of $376 \mathrm{bp}$ from the rat IGF-I cDNA, containing part of the A domain, the entire D and E domains and part of the $3^{\prime}$-untranslated region was generated in order to simultaneously quantify IGF-Ia and IGF-Ib mRNAs, yielding protected fragments of 224 and $376 \mathrm{bp}$ respectively. This is due to a $52 \mathrm{bp}$ insert present in the $\mathrm{E}$ domain resulting in two different transcripts depending on whether exon 4 is spliced to exon 5 (Eb region: IGF-Ib) or exon 6 (Ea region: IGF-Ia). For the protection assay this template was linearized with HindIII and transcribed with T7 RNA polymerase (Lowe et al. 1988).

Cyclophilin The rat cyclophilin cDNA was a $132 \mathrm{bp}$ fragment linearized with ApaI and transcribed in order to generate the antisense probe with SP6 polymerase following previously described methods (Danielson et al. 1988).

\section{Ribonuclease protection assay (RPA)}

RNA was extracted using the Chomczynski and Sacchi (1987) method. In the RPA, total RNA of each individual rat was hybridized overnight with approximately 600000 c.p.m. labeled antisense rat IGF-I riboprobe at $45^{\circ} \mathrm{C}$. The hybridization solution contained $75 \%(\mathrm{vol} / \mathrm{vol})$ formamide, $80 \mathrm{mM}$ Tris- $\mathrm{HCl} \mathrm{pH} 7 \cdot 6,4 \mathrm{mM}$ EDTA, $1 \cdot 6 \mathrm{M} \mathrm{NaCl}$ and $0 \cdot 4 \%$ SDS. After hybridization, samples were digested using RNAse A $(40 \mathrm{mg} / \mathrm{ml})$ and RNAse T1 $(2 \mathrm{mg} / \mathrm{ml})$ for $1 \mathrm{~h}$ at $30{ }^{\circ} \mathrm{C}$. Protected hybrids were isolated by ethanol precipitation after phenol-chloroform extraction and separated according to size on an $8 \%$ polyacrylamide/8 M urea denaturing gel. Gels were exposed to X-ray film (Kodak, Cambridge, UK) at $-80{ }^{\circ} \mathrm{C}$ for $24-96 \mathrm{~h}$. Quantitation of the intensities of the autoradiography bands corresponding to protected hybrids was done by densitometric scanning using AdobePhotoshop 2.0 and NIH-Image 1.47 programs for the Apple Macintosh (Wpertino, CA, USA). All samples were hybridized at the same time with cyclophilin in order to correct for the differences in gel loading. 
Table 1 Body weight and serum parameters in 6- and 11-week-old lean and obese Zucker rats. Values are means \pm S.E.M. $(n=5)$

\begin{tabular}{|c|c|c|c|c|c|c|}
\hline & $\begin{array}{l}\text { Body weight } \\
\text { (g) }\end{array}$ & $\begin{array}{l}\text { Glucose } \\
(\mathrm{mg} / \mathrm{dl})\end{array}$ & $\begin{array}{l}\text { Insulin } \\
(\mathrm{mU} / \mathrm{ml})\end{array}$ & I/Glu & $\begin{array}{l}\text { Rat GH } \\
(\mathrm{ng} / \mathrm{ml})\end{array}$ & $\begin{array}{l}\text { IGF-I } \\
(\mathrm{ng} / \mathrm{ml})\end{array}$ \\
\hline \multicolumn{7}{|c|}{6 weeks } \\
\hline Lean & $162 \pm 3 \cdot 3$ & $164 \pm 2 \cdot 7$ & $44 \cdot 7 \pm 6 \cdot 5$ & $0 \cdot 24 \pm 0 \cdot 04$ & $2 \cdot 7 \pm 1 \cdot 1$ & $694 \cdot 4 \pm 28$ \\
\hline Obese & $200 \pm 3 \cdot 5^{* * *}$ & $155 \pm 5 \cdot 0$ & $138 \pm 10 \cdot 0^{* * *}$ & $0.92 \pm 0.08^{* * *}$ & $1 \cdot 7 \pm 0 \cdot 9$ & $774 \cdot 6 \pm 26$ \\
\hline \multicolumn{7}{|c|}{11 weeks } \\
\hline Lean & $257 \pm 3 \cdot 7$ & $142 \pm 5 \cdot 2$ & $46 \cdot 3 \pm 3 \cdot 0$ & $0.32 \pm 0.02$ & $4 \cdot 3 \pm 1 \cdot 2$ & $1516 \pm 121$ \\
\hline Obese & $381 \pm 6 \cdot 7^{* * *}$ & $148 \pm 5 \cdot 0$ & $147 \pm 14 \cdot 0^{* * *}$ & $1 \cdot 0 \pm 1 \cdot 0^{* \star *}$ & $2 \cdot 4 \pm 0 \cdot 9$ & $1439 \pm 182$ \\
\hline
\end{tabular}

$* * *<0 \cdot 001$ vs lean animals at the same age.

\section{Statistical analysis}

All values are means \pm s.E.M. The statistical significance of differences between values was calculated by unpaired Student's $t$-test and/or variance analysis. The differences were considered statistically significant when $P$ values were below $0 \cdot 05$.

\section{Results}

Six-week-old lean and obese Zucker rats

As shown in Table 1, at 6 weeks obese rats were already significantly heavier that lean controls. Serum IGF-I levels were comparable between phenotypes, in the presence of reduced $\mathrm{GH}$ levels in obese rats. Statistics for $\mathrm{GH}$ were avoided because some rats showed GH levels below the limit of detection of the RIA and were arbitrarily assigned the minimum value of sensitivity of the assay. As already described, obese rats showed no significant differences in glucose levels compared with lean, but were severely hyperinsulinemic and had increased basal insulin/glucose (I/Glu) ratio as an expression of their insulin resistance (Bray 1979).

IGF-I mRNA levels in tissues of 6-week-old lean and obese Zucker rats and its relative expression are shown in Figs 1 and 2 respectively. Both IGF-I transcripts were present in the liver, the IGF-Ib transcript being significantly decreased in obese rats vs lean (relative units; $69 \pm 10 \%$ vs $100 \pm 2 \%, P<0 \cdot 05)$ and the IGF-Ia transcript being similar ( $99 \pm 2 \%$ vs $100 \pm 5 \%$ ). In contrast IGF-Ib was barely detectable in extrahepatic tissues (unmeasurable in kidney and absent in heart, aorta or skeletal muscle) whereas IGF-Ia was clearly detectable. At this age we found no significant differences in IGF-I mRNA expression between obese animals and their lean littermates for aorta, kidney or skeletal muscle while there was an increased amount in the heart - left ventricle - of obese rats $(119 \pm 6 \cdot 6 \%$ vs $95 \pm 2 \cdot 8 \%, P<0 \cdot 05)$.

\section{Eleven-week-old lean and obese Zucker rats}

At 11 weeks lean and obese rats showed an increase of weight associated with the progression of age, the difference in body weight of obese rats vs lean controls being more evident than at 6 weeks. Serum IGF-I levels were comparable between phenotypes, in the presence of reduced $\mathrm{GH}$ levels in obese rats. As was the case at 6 weeks, obese rats showed similar glucose levels compared with the lean ones, severe hyperinsulinemia and an increased I/Glu ratio.

IGF-I mRNA levels in tissues of 11-week-old lean and obese Zucker rats and their relative expression are shown

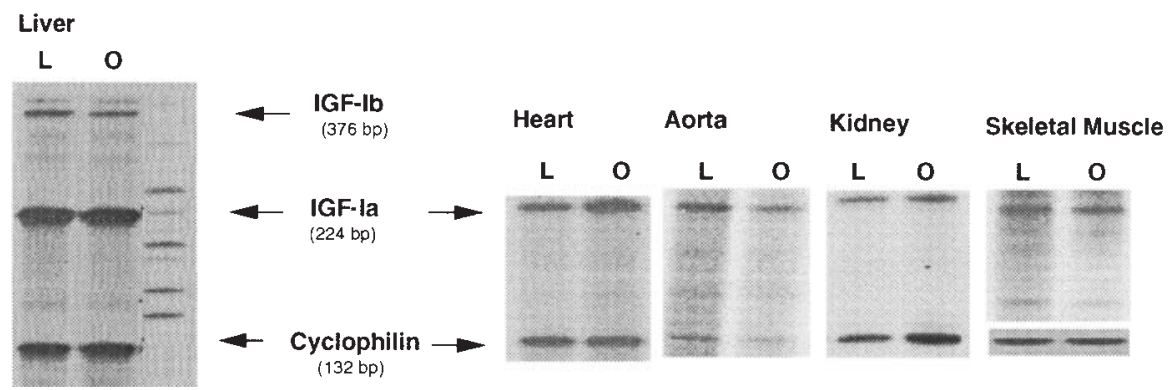

Figure 1 RPA of IGF-I mRNA levels in liver, heart, aorta, kidney and skeletal muscle from 6-week-old lean $(\mathrm{L})$ and obese $(\mathrm{O})$ Zucker rats. Ten to twenty micrograms total RNA from each tissue were subjected to solution hybridization/RPA using the antisense probes described in Materials and Methods. The position of each protected fragment is indicated by an arrow. 


\section{A. IGF-la}

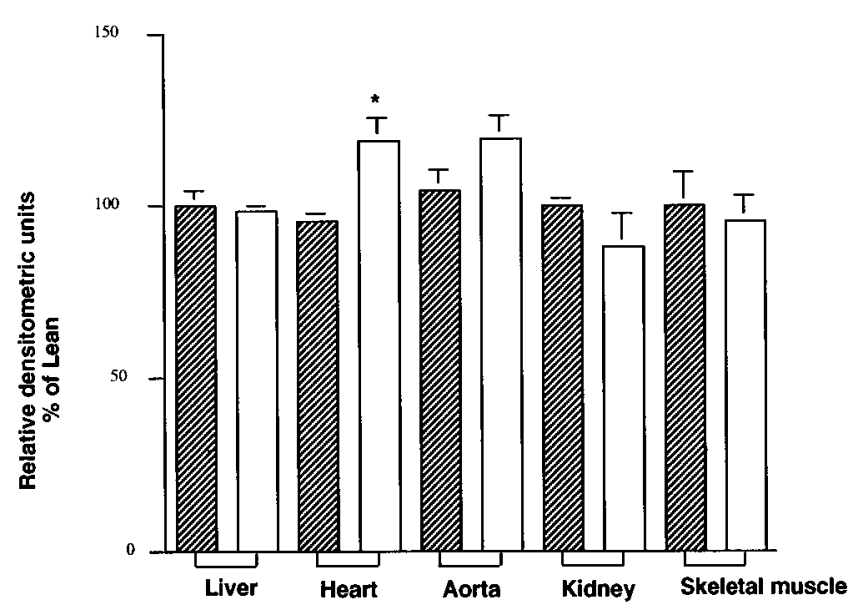

B. IGF-Ib

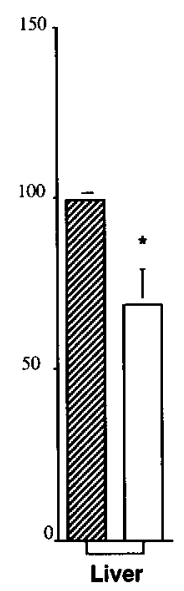

Figure 2 Relative levels of IGF-I mRNA expression in tissues of lean (hatched columns) and obese (open columns) Zucker rats at 6 weeks of age. After correction of both transcripts for cyclophilin levels, relative densitometric units were adjusted so that the ratio obtained from tissues of intact lean rats equaled 100. Results are means \pm S.E.M. $(n=3-5) .{ }^{*} P<0.05$ vs lean rats.

in Figs 3 and 4 respectively. At this age both hepatic IGF-I mRNA transcripts were decreased in the obese group, this decrease being more evident for the IGF-Ib transcript (relative units; IGF-Ia: $80 \pm 6 \%$ vs $100 \pm 1 \%, P<0 \cdot 05$; IGF-Ib: $65 \pm 5 \%$ vs $100 \pm 2 \%, P<0 \cdot 01)$. IGF-I mRNA expression compared with controls was: (1) similar for aorta extracts; (2) decreased for kidney and skeletal muscle extracts (kidney: $76 \pm 3 \%$ vs $100 \pm 4 \%, P<0 \cdot 05$; muscle: $59 \pm 4 \%$ vs $100 \pm 2 \%, P<0 \cdot 001$ ); and (3) increased for left-ventricle (114 $\pm 2 \%$ vs $100 \pm 9 \%, P<0 \cdot 05)$.

To confirm that extrahepatic tissues from obese Zucker rats showed GH dependence in conditions of absolute deprivation, we measured IGF-I mRNA amounts in liver and extrahepatic tissues from 11-week-old hx obese rats before and 4 and $8 \mathrm{~h}$ after acute rhGH administration (skeletal muscle not done). Figure 5 shows the quantitation of IGF-Ia and IGF-Ib transcripts in this group of rats. In the liver, rhGH administration increased 10 times the IGF-Ib and 2.5 times the IGF-Ia transcripts over basal values. Additionally in all the extrahepatic tissues studied, exogenous rhGH was able to induce IGF-I gene expression. A remarkable response was observed in aorta and heart where basal lGF-I amount was very low in the absence of GH.

\section{Discussion}

At the two ages studied obese and GH-deficient Zucker rats had serum levels of IGF-I similar to those of lean littermates in the presence of decreased hepatic mRNA expression, which was more marked at 11 weeks. Extra- hepatic IGF-I mRNA showed different patterns of expression with decreased levels in skeletal muscle and kidney at 11 weeks, normal levels in aorta at both ages and increased levels in heart at both ages. At present the factors that regulate gene expression of IGF-I in adult extrahepatic tissues and the molecular basis for the tissue differences in GH responsiveness are unknown. Obese Zucker rats develop progressive and partial GH deficiency through adult life (Gelato \& Berelowitz 1994) and provide a useful model to evaluate $\mathrm{GH}$ dependence in conditions more physiological than $\mathrm{GH}$ deprivation by hypophysectomy or transgenic models. Conscious of the limitations derived from the analysis of only one sample of serum GH, we chose for our purpose animals of two ages where the degree of GH deficiency in obese rats is well established. Thus, it has been demonstrated that plasma levels of GH, pulsatile GH release, pituitary $\mathrm{GH}$ concentration, and mRNA expression are reduced in obese male rats when compared with lean littermates, and that this defect is maximal at 10-12 weeks of age (Finkelstein et al. 1986, Ahmad et al. 1990, Tannenbaum et al. 1990, Leidy et al. 1993).

IGF-I of endocrine action is primarily derived from liver and $\mathrm{GH}$ has a crucial role in its synthesis and secretion (Schwander et al. 1983). Hepatic IGF-I mRNA expression in GH-deficient models such as aging rats or dwarfism is diminished in direct correlation to the low $\mathrm{GH}$ (Mathews et al. 1986, Tanaka et al. 1996, Velasco et al. 1998). In agreement with these reports, Zucker rats showed a decrease in hepatic IGF-I mRNA levels compared with lean which was more marked in 11-week-old rats. These results are in concordance with previous studies 
Liver

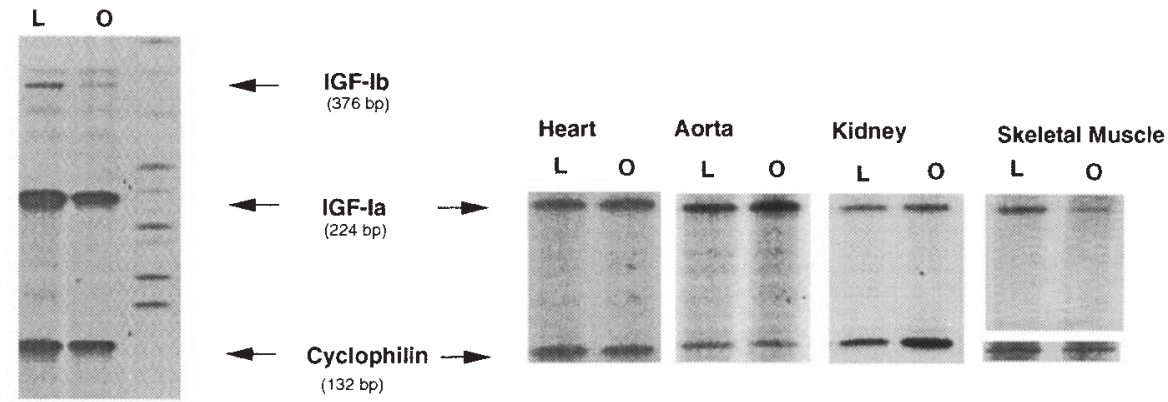

Figure 3 RPA of IGF-I mRNA levels in liver, heart, aorta, kidney and skeletal muscle from 11-week-old lean (L) and obese $(\mathrm{O})$ Zucker rats. Ten to twenty micrograms total RNA from each tissue were subjected to solution hybridization/RPA using the antisense probes described in Materials and Methods. The position of each protected fragment is indicated by an arrow.

performed in our laboratory where we found that hepatic IGF-I and insulin-like growth factor-binding protein-3 (IGFBP-3) mRNA expression in 11-week-old obese Zucker rats under different GH conditions tightly correlated with GH levels (Melián et al. 1997). However, obese rats had serum IGF-I levels comparable to lean at both ages, in spite of $\mathrm{GH}$ differences. In fact, as occurs in children with idiopathic obesity, obese Zucker rats have normal or increased rates of linear growth accompanied by normal or increased circulating IGF-I levels (Vignolo et al. 1988, Nguyen-Yamamoto et al. 1994). Moreover, obese rats, like sheep or humans, show a greater response to exogenous GH in serum IGF-I compared with lean controls (Nguyen-Yamamoto et al. 1994, McCann et al. 1997). It has been suggested that obesity-associated hyperinsulinemia could be responsible for this finding by directly increasing hepatic mRNA transcription, as apparently occurs in primary cultures of hepatocytes, even in the absence of GH (Boni-Schnetzler et al. 1991). Our data do not support this hypothesis since severely hyperinsulinemic obese rats showed a progressive decrease in liver IGF-I mRNA levels compared with lean as GH deficiency progressed. Moreover, hyperinsulinemia was not associated with an increase in the hepatic IGF-I amount under
A. IGF-Ia

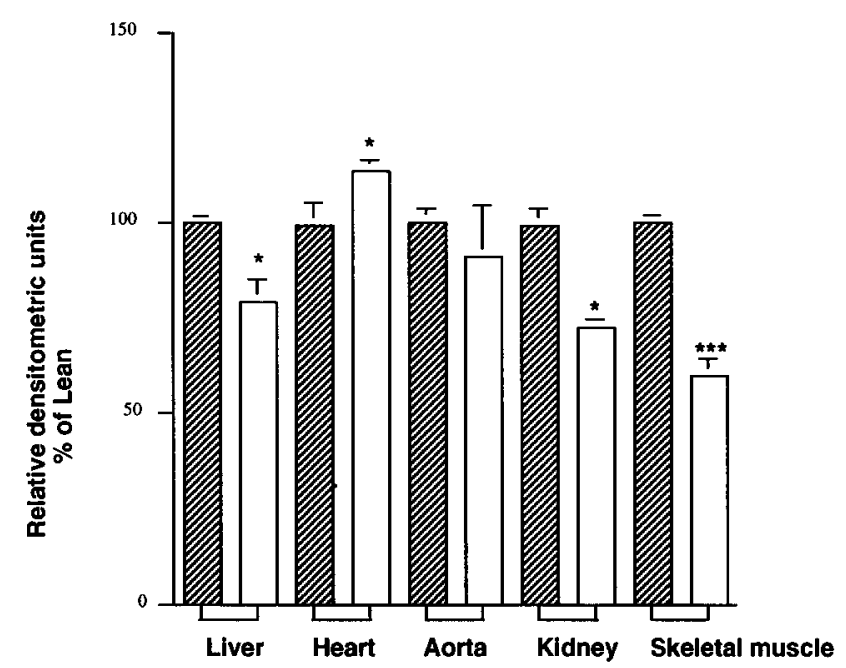

B. IGF-Ib

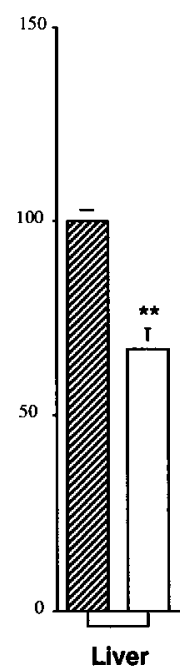

Figure 4 Relative levels of IGF-I mRNA expression in tissues of lean (hatched columns) and obese (open columns) Zucker rats at 11 weeks of age. After correction of both transcripts for cyclophilin levels, relative densitometric units were adjusted so that the ratio obtained from tissues of intact lean rats equaled 100. Results are means \pm S.E.M. $(n=3-5) .{ }^{*} P<0 \cdot 05$, ${ }^{* *} P<0 \cdot 01$ and ${ }^{* * * P}<0 \cdot 001$ vs lean rats. 
A.

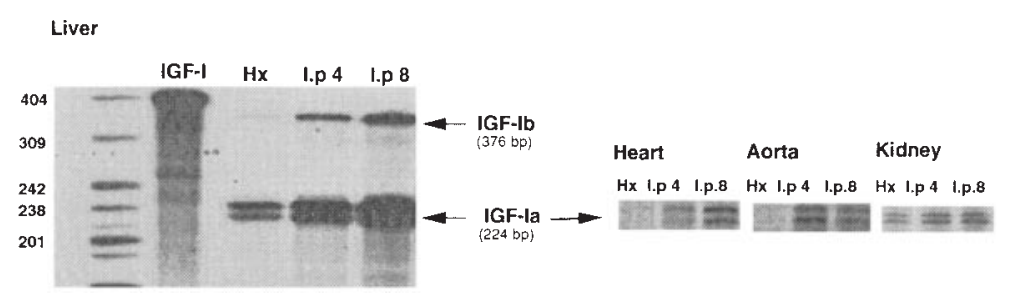

B.
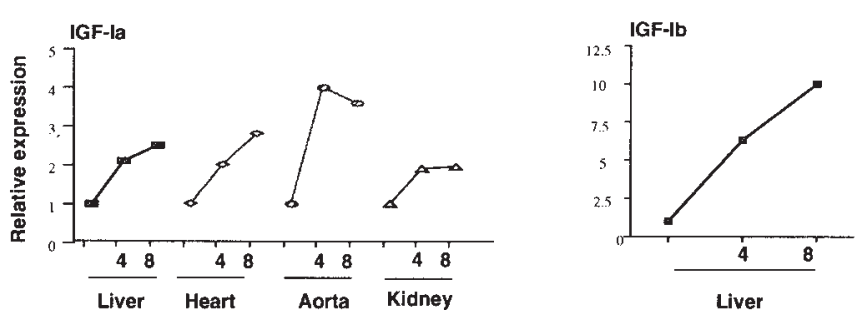

Figure 5 (A) Representative RPA of IGF-I mRNA levels in liver, heart, aorta and kidney from hx 11-week-old obese Zucker rats before and 4 or $8 \mathrm{~h}$ after acute rhGH treatment. (B) Relative levels of IGF-I mRNA expression. For this purpose the mean IGF-I band abundance in hx rats was assigned a value of 1 , since cyclophilin was also partially inducible by acute $\mathrm{GH}$ treatment.

comparable GH levels (Melián et al. 1997). Taken together, these data suggest that obesity-associated imbalance between low serum GH/normal serum IGF-I levels is primarily due to translational or post-translational events distal to the GH-dependent decrease of IGF-I expression in the liver. Changes in the final amount of free IGF-I secondary to modulation of IGFBPs by insulin and/or other nutritional factors could have a relevant role in this sense (Thissen et al. 1994). In fact obese Zucker rats have, compared with lean, low hepatic mRNA amounts but similar serum levels of IGFBP-3 (Nguyen-Yamamoto et al. 1994, Melián et al. 1997) suggesting that posttranscriptional events regulate serum levels of this binding protein (Albinston \& Herington 1992). On the other hand these rats show a $67 \%$ suppression of IGFBP-1 serum levels (Lewitt et al. 1994). This decrease could account for an increase in free IGF-I without alteration in total IGF-I levels as has been described in human obesity, showing direct correlation with hyperinsulinemia and inverse correlation with IGFBP-I levels (Frystyk et al. 1995).

The hepatic IGF-Ib transcript appears to be more tightly regulated by GH than IGF-Ia. Its decrease was already manifest at a younger age and was more marked in hx animals. Indeed several data support the view that the rat hepatic IGF-Ib mRNA variant of the IGF-I gene may be more sensitive to GH status (Mathews et al. 1986, Lowe et al. 1988, 1989, Tanaka et al. 1996, Melián et al. 1997, Velasco et al. 1998). A specific role for the Eb mRNA in directing hepatic IGF-I to the circulation on the basis of its post-natal presence, mainly in the liver, and its higher responsiveness to $\mathrm{GH}$ has been suggested, but there is little evidence to support this at present (Gilmour 1994).

Extrahepatic tissues express predominantly the IGF-Ia transcript and it is clear that, at least in rats, most tissues show ability to respond to acute $\mathrm{GH}$ treatment when severely deprived of GH by hx (Hynes et al. 1987, Roberts et al. 1987). Therefore the fact that extrahepatic tissues from hx Zucker rats elicit a remarkable response of local IGF-I mRNA expression after one i.p. rhGH dose is not surprising. However, the physiological role of $\mathrm{GH}$ on extrahepatic IGF-I gene expression should be evaluated in conditions of progressive and relative $\mathrm{GH}$ decline, when significant GH levels are still present. In our model we found a variable behavior in extrahepatic tissues of obese rats when compared with lean littermates. Skeletal muscle and kidney showed similar IGF-I mRNA expression at 6 weeks and decreased expression at 11 weeks with a more relevant reduction for skeletal muscle. In contrast, the level of aorta IGF-I mRNA was similar and that in left ventricle was higher than in controls at the two ages studied, suggesting in both cases its GH independence. Considering that aorta and heart showed almost undetectable levels of IGF-I mRNA in hx rats we suggest there might exist a differential threshold level of GH for each extrahepatic tissue which may condition full expression of the GHdependent component of IGF-I gene transcription. This threshold level would be higher for skeletal muscle, intermediate for kidney and lower for aorta and heart. This 
contention, consistent with data from other models of moderate GH deficits (Mathews et al. 1986, Lemmey et al. 1997, B Velasco, unpublished observations) could be due to tissue-specific affinities of the GH receptor for its ligand (Wells et al. 1993).

It could be argued that hyperinsulinemia associated with obesity in Zucker rats from 3 to 5 weeks of age could be attenuating a GH-dependent decrease of IGF-I mRNA expression in extrahepatic tissues, since insulin has been found to slightly increase IGF-I mRNA expression in the rat aorta in vivo (Murphy et al. 1990). Moreover, chronic insulin administration in pituitary-intact rats has been associated with an increase of IGF-I mRNA in kidney and heart from Sprague-Dawley rats, although not statistically supported (Salamon et al. 1989). Our data cannot exclude hyperinsulinemia as a cause of no decrease in IGF-I mRNA expression in heart and aorta from obese rats at the two ages. However, three arguments can be invoked against this hypothesis: (1) the consistency of our findings with those observed in the non-hyperinsulinemic GHdeficient lit/lit mouse (Mathews et al. 1986); (2) the fact that factitious hyperinsulinemia is not associated with overexpression of IGF-I in aorta, heart or skeletal muscle of normoglycemic diabetic rats (Bornfeld et al. 1992); and (3) the absence of increased IGF-I mRNA levels compared with lean in hearts of intact 11-week-old hyperinsulinemic obese rats killed $6 \mathrm{~h}$ after one dose of rhGH $(1.5 \mu \mathrm{g} / \mathrm{g}$ body weight) (data not shown).

Finally, the existence of differences between species in the steady-state level of IGF-I mRNA and its sensitivity to GH has been described (Moller et al. 1991). This fact has been more solidly established in skeletal muscle because of its easier access. IGF-I gene expression in muscle appears to be less sensitive to $\mathrm{GH}$ in humans, pigs or chickens (Weller et al. 1994, Hamilton et al. 1995, Tanaka et al. 1996) and more in sheep (Oldham et al. 1996). In rats, skeletal IGF-I mRNA expression seems to be highly sensitive to GH in hx and non-hx models (Murphy et al. 1987, Isgaard et al. 1989, Moller et al. 1991, Gosteli-Peter et al. 1994). Whether the severe local IGF-I decrease in skeletal muscle of 11-week-old obese rats has some relevance in the alteration of the skeletal structure and functionality of these animals is something not settled at the moment (King \& Betts 1994, He et al. 1995).

In summary, our data suggest the existence of considerable differences between adult tissues with regard to $\mathrm{GH}$ dependence of IGF-I gene expression. Models of partial and progressive $\mathrm{GH}$ deficit, as obesity or aging, can provide a useful system to elucidate $\mathrm{GH}$-dependent and -independent mechanisms in the regulation of IGF-I in physiological situations during adulthood.

\section{Acknowledgements}

The authors wish to thank Dr S Lamas for helpful comments. Drs E Hernandez, D LeRoith and S Ojeda are gratefully acknowledged for providing the cDNAs necessary to generate the riboprobes. We also thank Purification Mota for her technical assistance. This work was supported by a grant from the Spanish FIS (94/0355).

\section{References}

Ahmad I, Steggles AW, Carrillo AJ \& Filkenstein JA 1990 Developmental changes in levels of growth hormone mRNA in Zucker rats. Journal of Cellular Biochemistry 43 59-66.

Albinston AL \& Herington AC 1992 Tissue distribution and regulation of insulin-like growth factor (IGF)-binding protein-3 messenger ribonucleic acid (mRNA) in the rat: comparison with IGF-I mRNA expression. Endocrinology 130 497-502.

Boni-Schnetzler M, Schmid C, Meier PJ \& Froesch ER 1991 Insulin regulates insulin-like growth factor I mRNA in rat hepatocytes. American Journal of Physiology 260 E846-E851.

Bornfeld KE, Stottner A \& Arngvist HJ 1992 In vivo regulation of messenger RNA encoding insulin-like growth factor-I (IGF-I) and its receptor by diabetes, insulin and IGF-I in rat muscle. Journal of Endocrinology 135 203-211.

Bray GA 1979 The Zucker-fatty rat: a review. Federation Proceedings 36 148-153.

Chomczynski P \& Sacchi N 1987 Single-step method of RNA isolation by acid guanidinium thiocyanate-phenol-chloroform extraction. Analytical Biochemistry 162 156-159.

Danielson PE, Forss-Peter S, Brow MA, Calavetta L, Douglas J, Milner RJ \& Sutliffe JG 1988 p1B15: a cDNA clone of the rat mRNA encoding cyclophilin. DNA 7 261-267.

Daughaday WH \& Rotwein P 1989 Insulin-like growth factors I and II. Peptide, messenger ribonucleic acid and gene structures, serum and tissue concentrations. Endocrine Reviews 10 68-91.

D'Ercole A, Stiles A \& Underwood L 1984 Tissue concentrations of somatomedin C: further evidence for multiple sites of synthesis and paracrine or autocrine mechanisms of action. Proceedings of the National Academy of Sciences of the USA 81 935-939.

Finkelstein JA, Jervais P, Menadue M \& Willoughby JO 1986 Growth hormone and prolactin secretion in genetically obese Zucker rats. Endocrinology 118 1233-1236.

Frystyk J, Vestbo E, Skjaerbaek C, Mogensen CE \& Orskov H 1995 Free insulin-like growth factors in human obesity. Metabolism 44 $37-44$.

Gelato MC \& Berelowitz M 1994 Insulin-like growth factor-I and insulin-like growth factor binding proteins in the Zucker fatty rat: a case for differential tissue regulation. Advances in Experimental Medicine and Biology 343 387-396.

Gilmour RS 1994 The implications of insulin-like growth factor mRNA heterogeneity. Journal of Endocrinology 140 1-3.

Gosteli-Peter MA, Winterhalter K, Schmid C, Froesch ER \& Zapf J 1994 Expression and regulation of insulin-like growth factor-I (IGF-I) and IGF-I-binding protein messenger ribonucleic acid levels in tissues of hypophysectomized rats infused with IGF-I and growth hormone. Endocrinology 135 2558-2567.

Hamilton MT, Marsh DR, Criswell DS, Lou W \& Booth FW 1995 No effect of aging on skeletal muscle insulin-like growth factor mRNAs. American Journal of Physiology 269 R1183-R1188.

He D, Bolstad G, Brubback A \& Medbo JI 1995 Muscle fibre type and dimension in genetically obese and lean Zucker rats. Acta Physiologica Scandinavica 155 1-7.

Hynes MA, Van Wyk J, Brooks PJ, D'Ercole AJ, Jansen M \& Lund PK 1987 Growth hormone dependence of somatomedin-C/ insulin-like growth factor-I and insulin-like growth factor-II messenger ribonucleic acids. Molecular Endocrinology 1 233-242.

Isgaard J, Nilsson A, Vikman K \& Isacksson O 1989 Growth hormone regulates insulin-like growth factor-I mRNA in rat skeletal muscle. Journal of Endocrinology 120 107-112. 
King PA \& Betts JJ 1994 Insulin and Na-dependent alanine transport in skeletal muscle of obese Zucker $(\mathrm{fa} / \mathrm{fa})$ rats. American Journal of Physiology 276 R1606-R1610.

Leidy JW Jr, Romano TM \& Millard WJ 1993 Developmental and sex-related changes of the growth hormone axis in lean and obese Zucker rats. Neuroendocrinology 57 213-223.

Lemmey AB, Glassford J, Flick-Smith HC, Holly JMP \& Pell JM 1997 Differential regulation of tissue insulin-like growth factorbinding protein (IGFBP)-3, IGF-I and IGF type 1 receptor mRNA levels, and serum IGF-I and IGFBP concentrations by growth hormone and IGF-I. Journal of Endocrinology 154 319-328.

Lewitt MS, Saunders H, Phyual JL \& Baxter RC 1994 Regulation of insulin-like growth factor binding protein-I in rat serum. Diabetes $43232-239$.

Lowe WL Jr, Lasky SR, LeRoith D \& Roberts CT Jr 1988 Distribution and regulation of rat insulin-like growth factor I messenger ribonucleic acids encoding alternative carboxyl terminal E-peptides: evidence for differential processing and regulation in liver. Molecular Endocrinology 2 528-535.

Lowe WL Jr, Adamo M, Werner H, Roberts CT \& LeRoith D 1989 Regulation by fasting of rat insulin-like growth factor I and its receptor. Effects on gene expression and binding. Journal of Clinical Investigation 84 619-626.

McCann JP, Loo SC, Aalseth DL \& Abribat T 1997 Differential effects of GH stimulation on fasting and prandial metabolism and plasma IGFs and IGF-binding proteins in lean and obese sheep. Journal of Endocrinology 154 329-346.

Mathews LS, Norstedt G \& Palmiter RD 1986 Regulation of insulin-like growth factor I gene expression by growth hormone. Proceedings of the National Academy of Sciences of the USA 83 9343-9347.

Melián E, Velasco B, Barrios R \& Sanchez Franco F 1997 Basal and growth-hormone induced hepatic messenger ribonucleic acid expression of insulin-like growth factor-I (IGF-I) and IGF-binding protein-3 is independent of hyperinsulinemia and increased energy status in the genetically obese Zucker rat. Endocrinology 138 1066-1071.

Moller CP, Arner P, Sonnenfeld T \& Norstedt G 1991 Quantitative comparison of insulin-like growth factor mRNA levels in human and rat tissues analyzed by solution hybridization assay. Journal of Molecular Endocrinology 7 213-222.

Murphy LJ, Bell GI, Duckworth ML \& Friesen HG 1987 Identification, characterization, and regulation of a rat complementary deoxyribonucleic acid which encodes insulin-like growth factor-I. Endocrinology 121 684-691.

Murphy LJ, Ghahary A \& Chakrabarti S 1990 Insulin regulation of IGF-I expression in rat aorta. Diabetes 39 657-662.

Nguyen-Yamamoto L, Deal CL, Finkelstein JA \& Van Vliet G 1994 Hormonal control of growth in the genetically obese Zucker rat. I. Linear growth, plasma insulin-like growth factor-I (IGF-I) and IGF-binding proteins. Endocrinology 134 1382-1388.
Oldham JM, Martyn J, Kirk SP, Napier JR \& Bass JJ 1996 Regulation of type 1 insulin-like growth factor (IGF) receptors and IGF-I mRNA by age and nutrition in ovine skeletal muscles. Journal of Endocrinology 148 337-346.

Roberts CT, Lasky SR, Lowe WL Jr, Seaman WT \& LeRoith D 1987 Molecular cloning of rat insulin-like growth factor I complementary deoxyribonucleic acids: differential messenger ribonucleic acid processing and regulation by growth hormone in extrahepatic tissues. Molecular Endocrinology 1 243-248.

Salamon EA, Luo J \& Murphy LJ 1989 The effect of acute and chronic insulin administration on insulin-like growth factor-I expression in the pituitary-intact and hypophysectomised rat. Diabetologia 32 348-353.

Schwander JC, Hauri C, Zapf J \& Froesch ER 1983 Synthesis and secretion of insulin-like growth factor and its binding protein by perfused rat liver: dependence on growth hormone status. Endocrinology 113 297-305.

Tanaka M, Hayashida Y, Sakaguchi K, Ohkubo T, Wakita M, Hoshino S \& Nakashima K 1996 Growth hormone-independent expression of insulin-like growth factor I messenger ribonucleic acid in extrahepatic tissues of the chicken. Endocrinology 137 30-34.

Tannenbaum GS, Lapointe M, Gurd W \& Finkelstein JA 1990 Mechanisms of impaired growth hormone secretion in genetically obese Zucker rats: roles of growth hormone-releasing factor and somatostatin. Endocrinology 127 3087-3095.

Thissen JP, Ketelslegers JM \& Underwood LE 1994 Nutritional regulation of the insulin-like growth factors. Endocrine Reviews $\mathbf{1 5}$ 80-101.

Velasco B, Cacicedo L, Escalada J, Lopez Fernandez J \& Sanchez Franco F 1998 Growth hormone gene expression and secretion in aging rats is age dependent and not age associated weight increase related. Endocrinology 139 1314-1320.

Vignolo M, Naselli A, Di Battista E, Mostert M \& Aircadi G 1988 Growth and development in simple obesity. European Journal of Pediatrics 147 242-244.

Weller PA, Dauncey MJ, Bates PC, Brameld JM, Buttery PJ \& Gilmour RS 1994 Regulation of porcine insulin-like growth factor I and growth hormone receptor mRNA expression by energy status. American Journal of Physiology 266 E776-E785.

Wells JA, Cunninghan BC, Fuh G, Lowman HB, Bass SH, Mullcerrin MG, Ultsch M \& Devos AM 1993 The molecular basis of growth hormone-receptor interactions. Recent Progress in Hormone Research 48 253-275.

Received 11 May 1998

Revised manuscript received 17 August 1998

Accepted 1 September 1998 